\title{
Adventure programming and travel for the 21st century
}

\author{
Reviewed by Glyn J. Thomas
}

Black, R., \& Bricker, Kelly S. (2015). Adventure programming and travel for the 21st century. State College, PA: Venture Publishing, Inc.

ISBN-13: 978-1-939476-04-3

This book is effectively a third edition of the original Venture Publishing texts Adventure Education (Miles \& Priest, 1990) and Adventure Programming (Miles \& Priest, 1999). This latest edition, edited by Rosemary Black and Kelly Bricker (2015), provides an additional focus on adventure travel because of the "need to refocus on sustainability and increased concerns for the health and well-being of our planet and inhabitants" (p. 3).

The book is divided into seven sections, which the editors describe as "trailmarkers." These sections are titled "Glancing Back and Trekking Forward in Adventure," "Places and Spaces for Adventure," "Diverse Outdoor Connections for the 21st Century," "Planning, Programming, and Managing Adventures," "Current Issues and Dilemmas in Adventure Programming and Travel," "Sustainable Adventure Management," and "Adventure Debrief." Across these seven sections there are 19 chapters, 13 of which are authored by Americans and the remaining six contributed by authorship teams that include Australian academics and professionals. This strong presence of Australian authors is likely due to the connections of editor Rosemary Black, an academic at Charles Sturt University in Australia. The more international feel of this latest offering from Venture Publishing is an improvement on previous editions. However, when reading the chapters written by American authors, I am still surprised by the Americentrism. Given the easy access and availability of research publications online, I find it surprising that some American authors still fail to draw on the high-quality work of many European, British, and Antipodean writers.

To make the text more relevant to a wider readership, the editors have done well to include case studies from practitioners and academics from around the world within each chapter. In most chapters, these case studies provide a relevant practical application of the theories or principles discussed in the chapter. I was a bit perplexed by the case study provided for Wattchow and Brown's chapter on place responsiveness, as it could have been better aligned with the content of the chapter. In most other chapters, the case studies were excellent examples of theory in practice and could have easily been significant contributions to the book in their own right.
At first, I was a bit dubious about how well the focus on adventure travel would blend with adventure education given the potentially different goals and philosophies of education and tourism. However, I think the chapters on tourism provide some useful insights to issues that confront both educators and tourism professionals alike. It is positive for academics from outdoor education/recreation to be exposed to some of the research and thinking of tourism researchers and practitioners.

The book would be suitable as a course textbook for some adventure recreation/tourism courses, and each chapter and case study provides a set of discussion questions which can be used to facilitate student engagement. A compact disc is also provided with the book, which includes a document with weblinks to YouTube videos that can be used to supplement teaching within each of the book sections. The quality of the videos themselves varies considerably, but some of them would be useful as teaching tools. For academics teaching within an outdoor leadership or adventure tourism programme, I think there are definitely chapters and case studies that would be useful.

\section{References}

Black, R., \& Bricker, K. S. (2015). Adventure programming and travel for the 21st century. State College, PA: Venture Publishing.

Miles, J. C., \& Priest, S. (1990). Adventure education. State College, PA: Venture Publishing.

Miles, J. C., \& Priest, S. (1999). Adventure programming (2nd ed.). State College, PA.: Venture Publishing.

\footnotetext{
About the author

Glyn Thomas is a Senior Lecturer at the University of the Sunshine Coast in Queensland, Australia. He is the coordinator of a new Bachelor of Recreation and Outdoor Environmental Studies that started in 2016. He has worked in outdoor experiential education programmes in school and higher education contexts for more than 30 years and enjoys conducting research in the areas of facilitation, facilitator education, and fieldwork pedagogies.

Contact:gthomas2@usc.edu.au
} 